\title{
Is Intracanal Cryotherapy Effective in Reducing Postoperative Endodontic Pain? An Updated Systematic Review and Meta-Analysis of Randomized Clinical Trials
}

\author{
Amal Almohaimede *(D) and Ebtissam Al-Madi (D) \\ Department of Restorative Dental Sciences, Endodontic Division, College of Dentistry, King Saud University, \\ Riyadh 11451, Saudi Arabia; ealmadi@ksu.edu.sa \\ * Correspondence: aalmohaimede@ksu.edu.sa
}

check for

updates

Citation: Almohaimede, A.; Al-Madi, E. Is Intracanal Cryotherapy Effective in Reducing Postoperative Endodontic Pain? An Updated Systematic Review and Meta-Analysis of Randomized Clinical Trials. Int. J. Environ. Res. Public Health 2021, 18, 11750. https://doi.org/10.3390/ ijerph182211750

Academic Editor: Hassan Ziada

Received: 4 October 2021

Accepted: 4 November 2021

Published: 9 November 2021

Publisher's Note: MDPI stays neutral with regard to jurisdictional claims in published maps and institutional affiliations.

Copyright: (c) 2021 by the authors. Licensee MDPI, Basel, Switzerland. This article is an open access article distributed under the terms and conditions of the Creative Commons Attribution (CC BY) license (https:// creativecommons.org/licenses/by/ $4.0 /)$.

\begin{abstract}
This research aimed to assess the potency of intracanal cold therapy in diminishing postoperative endodontic pain. PubMed, Scopus, the Cochrane Library, EMBASE, the Web of Science, grey literature, and endodontic journals were used to identify randomized controlled clinical trials evaluating postoperative pain after a final irrigation with a cold irrigant (as an experimental group) and a room temperature irrigant (as a control group). The risk of bias was rated according to the Cochrane Collaboration's tool and the Grading Recommendation Assessment, Development, and Evaluation (GRADE) system was used to estimate the evidence quality. For the meta-analysis, a random effects model was utilized. The qualitative analysis contained 16 studies and the quantitative analysis contained 9 studies. The experimental groups showed a reduction in postoperative pain at $6 \mathrm{~h}$ (mean difference $(\mathrm{MD})=-1.11 ; p=0.0004 ; \mathrm{I}^{2}=72 \%$; low quality evidence), $24 \mathrm{~h}$ (MD = -1.08; $p=0.003$; $\mathrm{I}^{2}=92 \%$; low quality evidence), $48 \mathrm{~h}\left(\mathrm{MD}=-0.38 ; p=0.04 ; \mathrm{I}^{2}=81 \%\right.$; low quality evidence), and $72 \mathrm{~h}$ $\left(\mathrm{MD}=-0.69 ; p=0.04 ; \mathrm{I}^{2}=90 \%\right.$; low quality evidence). A higher quality of evidence from more clinical trials is needed.
\end{abstract}

Keywords: cold therapy; cryotherapy; endodontic pain; intracanal cryotherapy

\section{Introduction}

One of the essential parts of endodontic therapy is to prevent and manage postendodontic pain [1]. The prevalence of postoperative pain after endodontic treatment ranges between 3 and 58\% [2]. The reported frequency of teeth that showed persistent pain at 6 months or more after root canal treatment varied from 4.9-12\% [3-7]. Moreover, the prevalence and severity of pain were not shown to differ significantly among the number of root canal treatment visits [8]. Postoperative pain following endodontic treatment is due to chemical, mechanical, or microbial injury to the periradicular tissue [9]. Several techniques and treatments have been described in the literature to control postoperative pain in endodontics including the prescription of medication [10-12], the use of intracanal therapies [13-15], and occlusal reduction [16]. Nevertheless, each technique and treatment has its own disadvantages. Nonsteroidal anti-inflammatory drugs (NSAIDs) have been documented to have harmful effects on several body systems such as the gastric mucosa and hepatic system [17]. Furthermore, the initial exposure to opioids might lead to respiratory depression, nausea, and the risk of long-term use, abuse, and overdose [18]. The use of intracanal therapies (such as calcium hydroxide, laser application, and analgesic solutions) and occlusal reduction have contradictory effects on reducing postoperative endodontic pain in the literature $[19,20]$. Cryotherapy involves reducing the tissue temperature for curative purposes [21]. It was first used by the ancient Egyptians circa 3000 BCE to cure injuries and decrease inflammation [22]. Since 1960, it has been used in medicine to relieve the pain of sports injuries [23]. Its mechanism of action in reducing pain involves decreasing the tissue temperature and reducing the flow of blood and metabolic activity [24]. In dental practice, 
cryotherapy reduces edema and postoperative pain following third molar extractions [25]. In endodontics, cryotherapy was introduced in several randomized clinical trials (RCTs) as an intracanal irrigation method to reduce postoperative endodontic pain [26-62]. However, the evidence from these RCTs has been debatable; accordingly, this systematic review and meta-analysis aimed to assess the potency of intracanal cryotherapy in diminishing postoperative endodontic pain.

\section{Materials and Methods}

\subsection{Study Protocol}

This research was recorded with the International Prospective Register of Systematic Review (PROSPERO CRD42021253682). The recommendations of the Preferred Reporting Items of Systematic Reviews and Meta-Analysis (PRISMA) statement were followed by the authors [63].

\subsection{PICOS Eligibility Criteria}

Participants $(\mathrm{P})$ : Adult patients $(\geq 18$ years old) with permanent teeth that had pulpal or periradicular pathosis and who were undergoing nonsurgical root canal therapy.

Intervention (I): A cold irrigant was used as the final irrigant.

Comparator $(\mathrm{C})$ : A room temperature irrigant was used as the final irrigant.

Outcome (O): Postoperative pain level from day one.

Study design (S): Randomized controlled clinical trials evaluating postoperative pain after instrumentation or obturation.

\subsection{Database Sources and Search Strategy}

The main electronic databases were utilized to identify the studies: MEDLINE through PubMed (1952-June 2021); Scopus (2004-June 2021); EMBASE (1984-June 2021); the Cochrane Library (1993-June 2021); and the Web of Science (1997-June 2021). In addition, a grey literature search was carried out on OpenGrey and Google Scholar. Moreover, endodontic specific journals such as the Australian Endodontic Journal, the International Endodontic Journal, the Journal of Endodontics, Clinical Oral Investigations, and Endodontics \& Dental Traumatology were searched for relevant articles. The lists of references of the selected studies were manually searched for any relevant documented articles.

On the basis of the PICOS format, the eligible studies were included by defining the MeSH (Medical Subject Headings) terms, keywords, and synonyms in the search strategy. The search terms were "cryotherapy", "intracanal cryotherapy", "cold therapy", "endodontic pain", "postoperative endodontic pain", and "endodontic cryotherapy". Studies published in the English language were included with no restrictions on the publication date. Case reports, review articles, nonhuman studies, and retreatment cases were excluded. Duplicate articles present in more than one database were considered to be only one article.

\subsection{Selection of Studies and Data Collection}

The titles and abstracts were independently screened by two evaluators (A.A. and E.A.-M.). They judged the study eligibility, rated the risk of bias, and examined the reported data [64]. If data applicable to the inclusion criteria were not found in the abstract or the abstract was missing, then the article was accessed for full-text reading. Any controversy between the reviewers was discussed. The data extraction was conducted using an Excel spreadsheet (version 14.7.1, Microsoft, Redmond, WA, USA). The retrieved data included the year of publication and the authors of the study, the study design, the pulpal and periapical diagnosis, the age range of participants, the type of teeth, preoperative pain in the experimental and control groups, the postoperative drug prescription, the pain evaluation scale utilized, the total sample size, the irrigation methods utilized, the type and concentration of irrigant utilized, the irrigant activation, and postoperative pain one day minimum after the procedure, the results, and the conclusion. The risk of bias was rated according to Cochrane Collaboration's tool for assessing the risk of bias in randomized 
trials (RoB 2) [65]. For the meta-analysis, RevMan software (version 5.4; The Cochrane Collaboration, London, UK) was used. To indicate the effect estimate, the mean differences (MDs) with $95 \%$ confidence intervals (CIs) and a random effects model were used. The $\mathrm{I}^{2}$ index was used to test the heterogeneity. The quality of evidence was judged using the GRADE system (www.GradeWorking-Group.org, accessed on the 1 September 2021) [66].

\section{Results}

A total of 33 studies remained for retrieval and an eligibility assessment after excluding ineligible and duplicated articles (Figure 1).

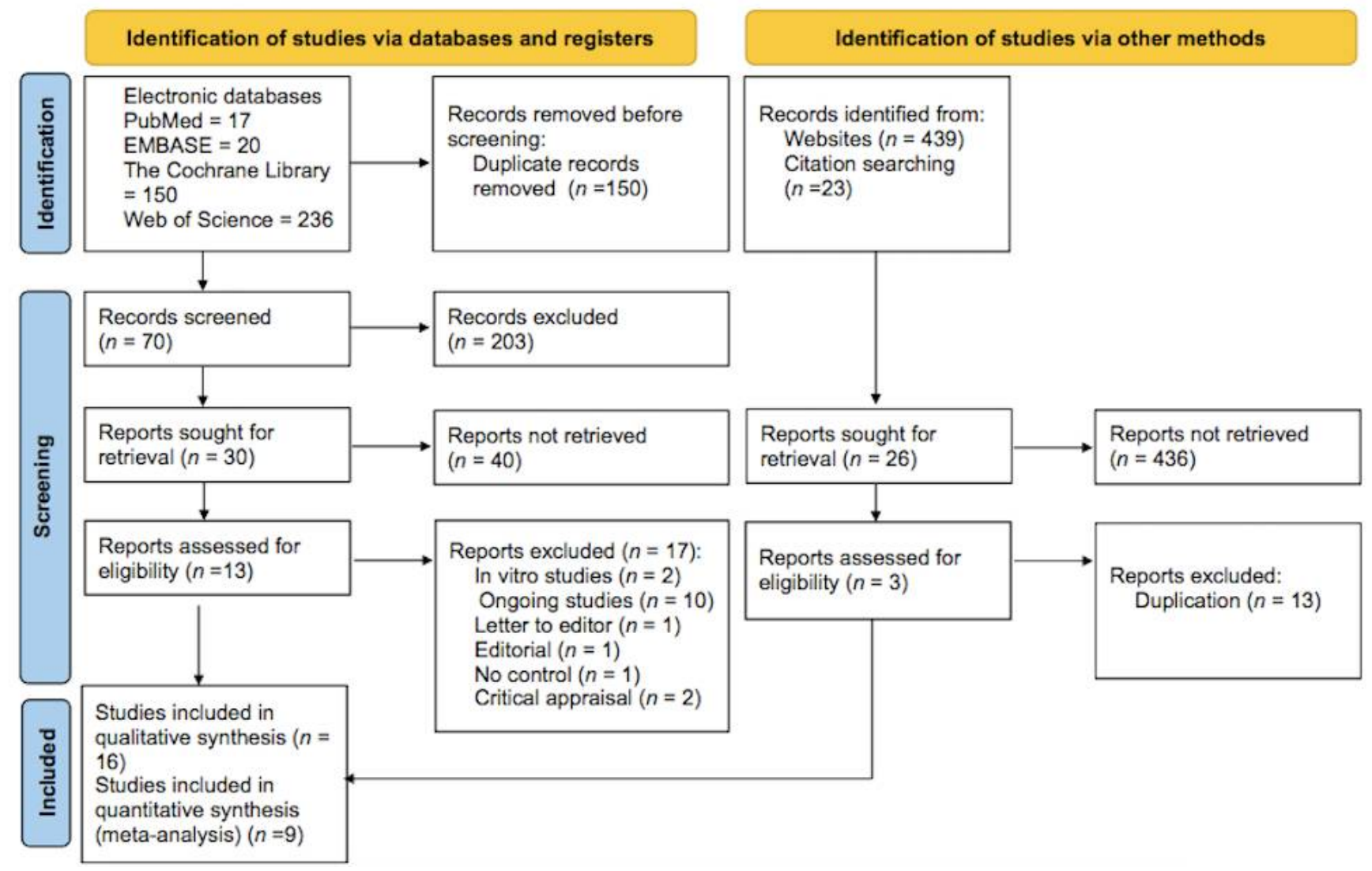

Figure 1. PRISMA 2020 flow diagram for the systematic reviews and meta-analysis.

Seventeen articles were eliminated due to the following causes: ten studies were still ongoing [26-35], two studies were in vitro [36,37], two studies were critical appraisals [38,39], one paper was a letter to the editor [40], one was an editorial paper [41], and one study had no control group [42]. Therefore, 16 studies were involved in the systematic review [43-58]. Seven of the sixteen studies documented their results as percentages, which were excluded from the meta-analysis $[43,44,47,50,52,55,56]$. Nine studies involving 878 participants were included in the meta-analysis $[45,46,48,49,51,53,54,57,58]$. The main features of the sixteen included articles are summarized in Table 1. 
Table 1. Summary of the main characteristics of the included studies.

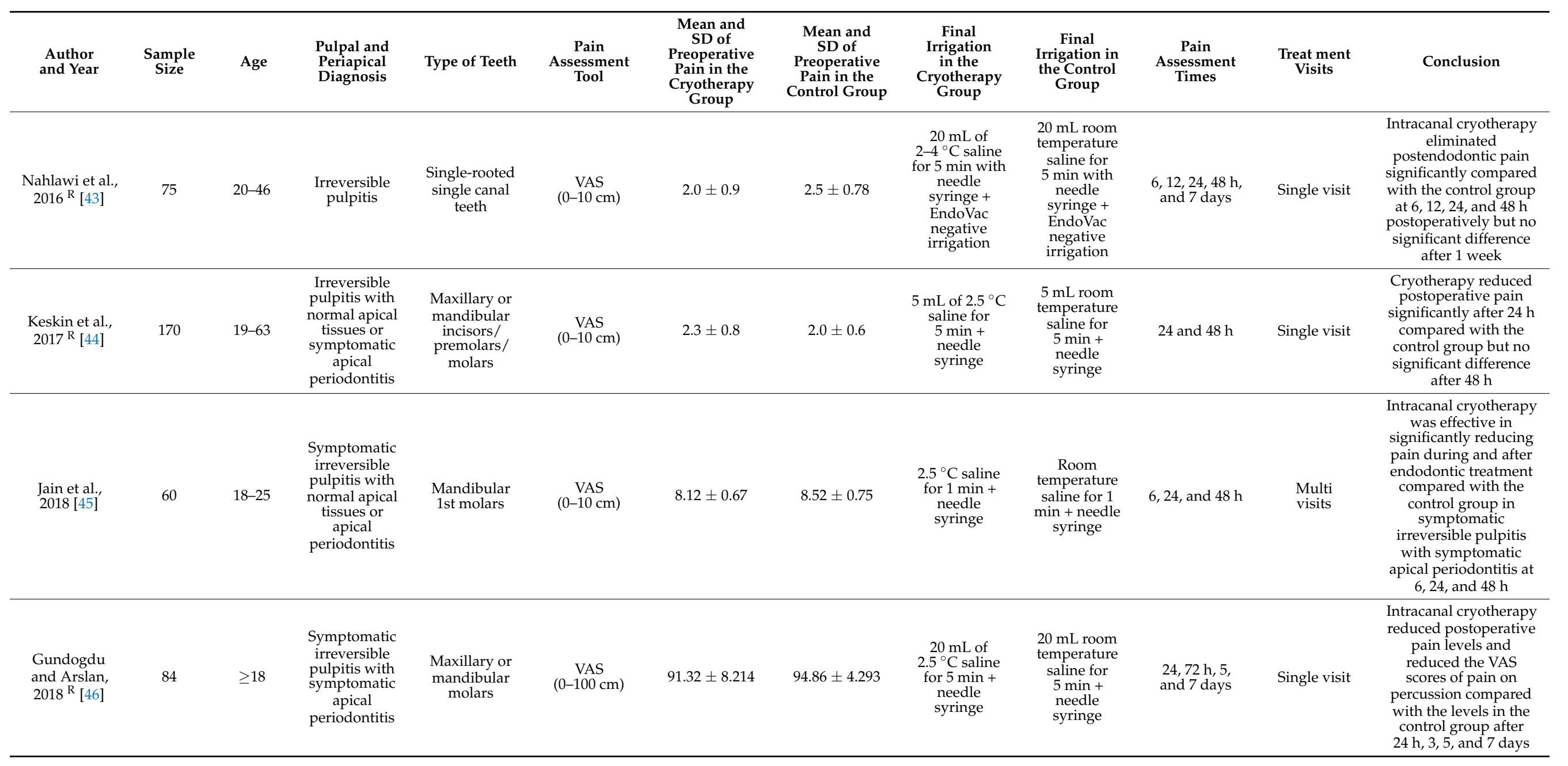


Table 1. Cont

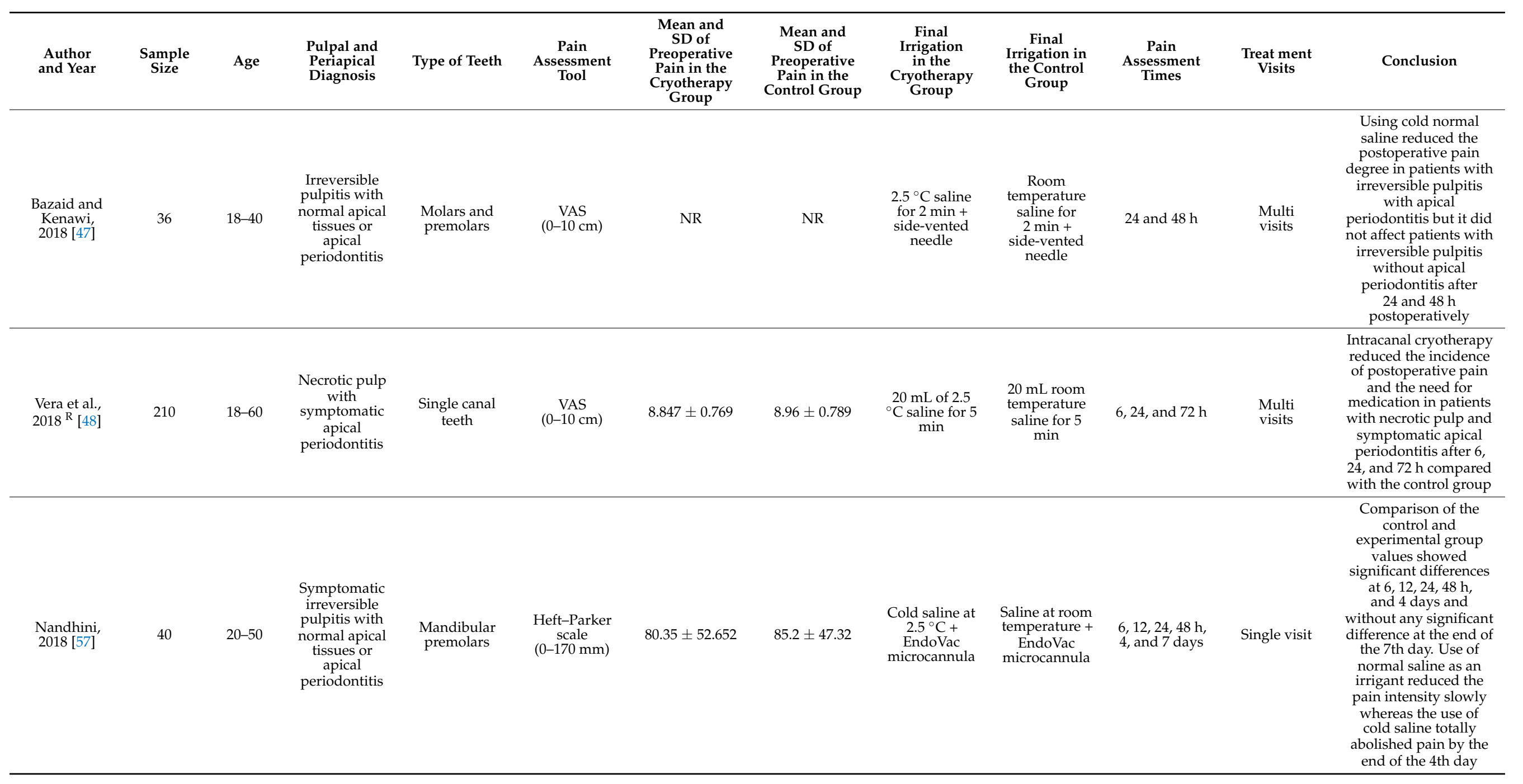


Table 1. Cont.

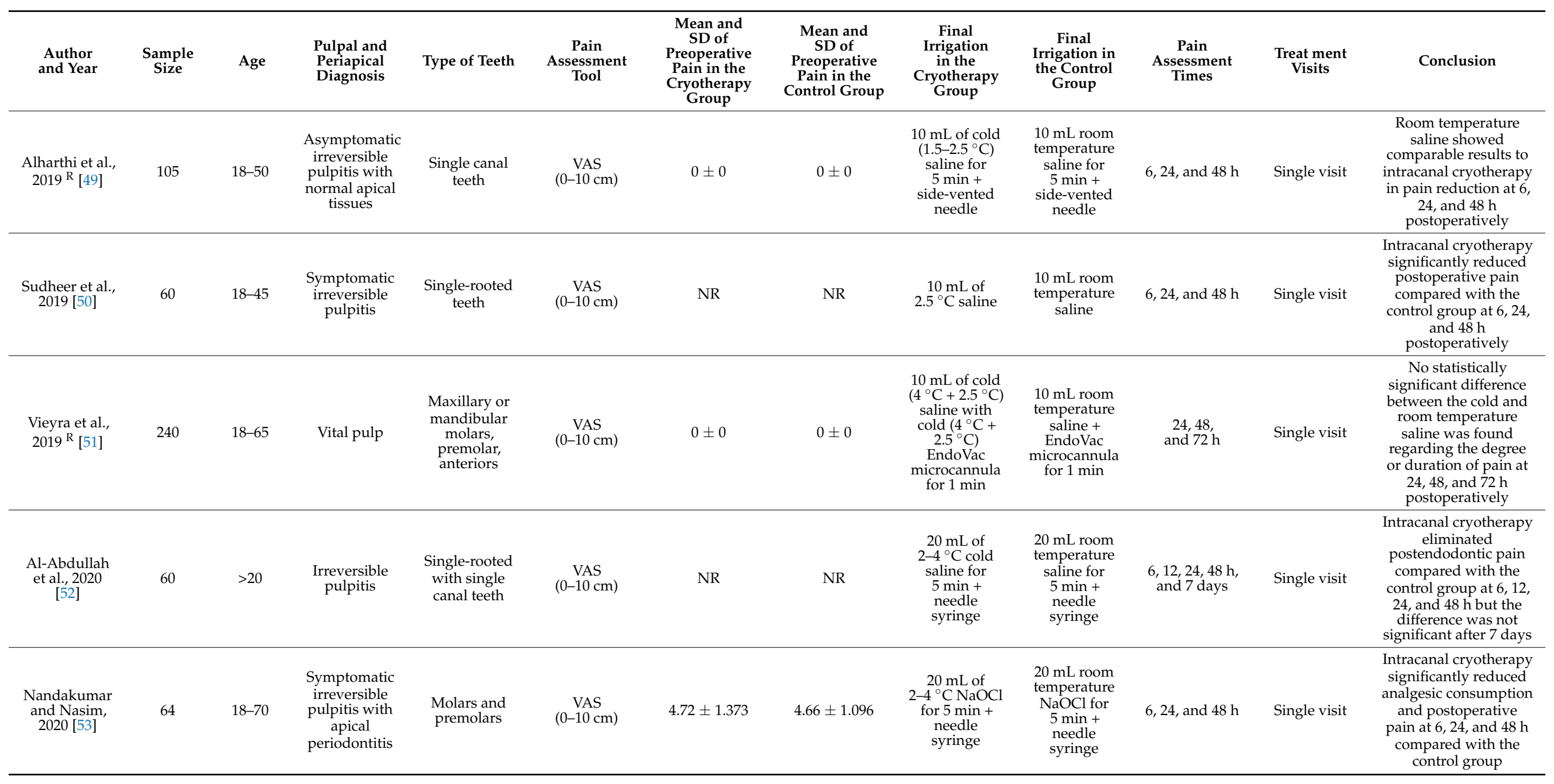


Table 1. Cont.

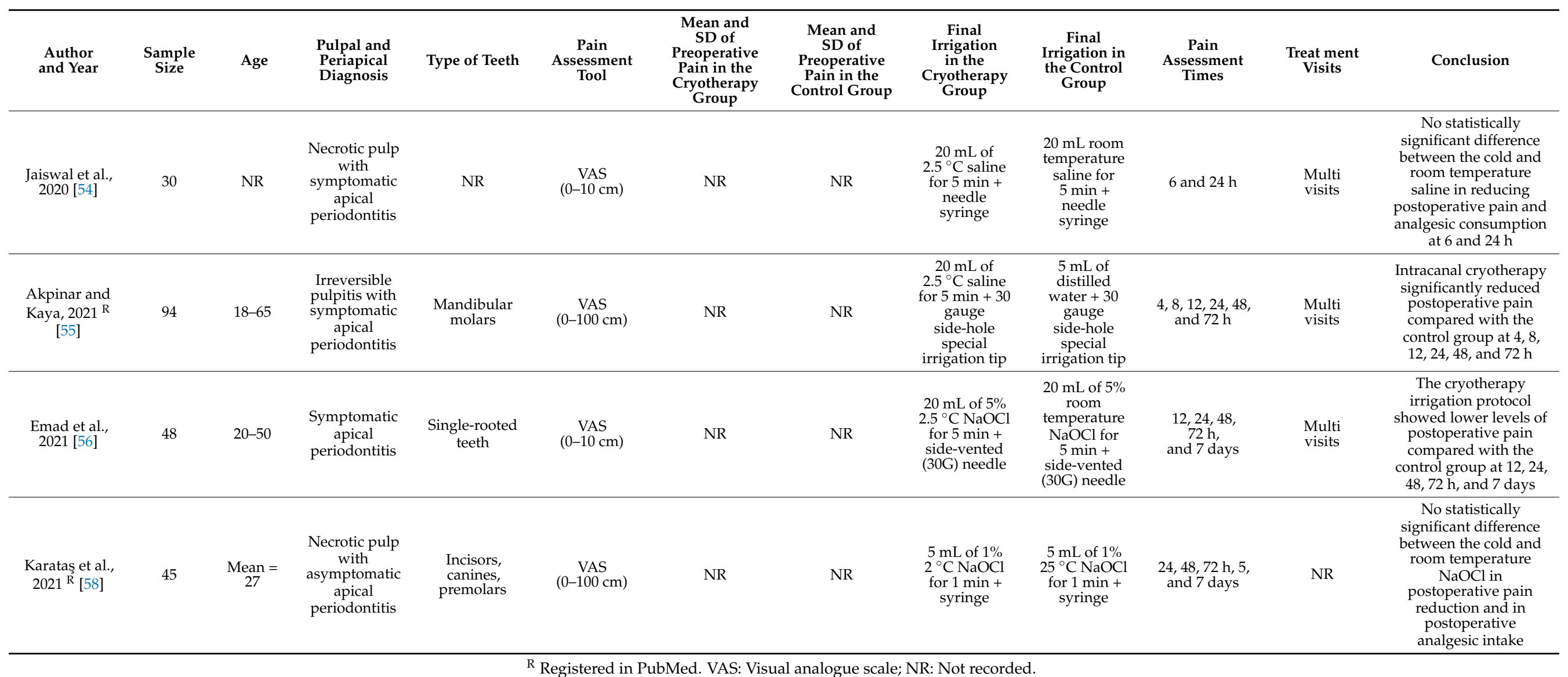


Eight of the sixteen articles consisted of two parallel groups [44,45,47,48,50,53,54,57], four studies had three parallel groups $[43,49,51,58]$, three studies had four parallel groups $[46,52,56]$, and one study had five parallel groups [55]. The number of participants in these studies ranged from 30 to 240 with ages ranging from 18 to 70 years diagnosed with irreversible pulpitis in 11 studies [43-47,49,50,52,53,55,57], necrotic pulp in 3 studies $[48,54,58]$, and pulpal and periradicular pathosis or normal periradicular tissues in 12 studies [44-49,53-58]. The assessment of postoperative pain ranged from day 1 to day 7 and it was measured using a visual analogue scale (VAS, $0-10 \mathrm{~cm}$ ) in 12 studies [43-45,47-54,56]. Three studies used the VAS (0-100) [46,55,58], one study used the Heft-Parker scale [57], and all of the scales were converted into a $0-10 \mathrm{~cm}$ VAS for statistical calculation standardization. Preoperative pain was evaluated in $13 \mathrm{stu}-$ dies [43-49,51,53-57] ranging from no pain in 2 studies [49,51] to mild pain in 2 studies $[43,44]$, moderate pain in 2 studies [53,54], and severe pain in 6 studies $[45-48,55,56]$. One study had fourteen patients with mild pain, twelve patients with moderate pain and fourteen patients with severe pain [57]. Three studies did not clearly describe the preoperative pain assessment $[50,52,58]$. The final cold irrigant used was either saline in most of the studies [43-52,55,57] or sodium hypochlorite ( $\mathrm{NaOCl})[53,54,56,58]$. The temperature of the final irrigant ranged from $1.5{ }^{\circ} \mathrm{C}$ to $4{ }^{\circ} \mathrm{C}$ and the volume was $5 \mathrm{~mL}[44,51,58]$, $10 \mathrm{~mL}$ [49-51], or $20 \mathrm{~mL}$ [43,46,48,52-56] for durations of $1 \mathrm{~min}$ [45,51,58], $2 \mathrm{~min}$ [47], or 5 min $[43,44,46,48,49,52-56]$. Two studies did not mention the duration [50,57]. EndoVac negative irrigation was used along with needle syringe activation in five studies $[43,44,48,51,57]$. Thirteen studies $(n=1219)$ compared the intracanal cryotherapy and control groups in terms of using analgesics postoperatively [43-46,48,50-55,57,58]. None of the patients in either group used analgesics in four studies [43-45,57] and fewer patients used analgesics in the intracanal cryotherapy group in eight studies $[46,48,50-54,58]$. The same number of patients in both groups used analgesics in one study [55]. Three studies did not mention any information about the use of analgesics postoperatively in either group $[47,49,56]$. Nine studies mentioned that root canal treatment was completed in one visit $[43,44,46,49-53,57]$, six studies performed root canal treatment in two visits $[45,47,48,54-56]$, and one study did not mention any information about the number of root canal treatment visits [58].The risk of bias (RoB 2) assessment for the included studies is summarized in Figure 2. According to the RoB 2 [65] assessment for the included sixteen studies, four studies were considered to have a high bias due to "deviations from the intended intervention" [47,50,54,57], two studies were considered to have a high bias due to "missing outcome data" [47,50], and five studies were considered to have a high bias for "measurement of the outcome" [45,50,54,55,57].

\subsection{Postoperative Pain at $6 \mathrm{~h}$}

Six studies $(n=450)$ revealed postoperative pain at $6 \mathrm{~h}[45,48,49,53,54,57]$. A metaanalysis demonstrated a significant statistical diminution in postoperative pain in the intracanal cold therapy group (experimental group) compared with the room temperature irrigant group (control group) (mean difference $(\mathrm{MD})=-1.11 ; 95 \%$ confidence interval $(\mathrm{CI})=-1.72$ to $-0.5 ; p=0.0004 ; \mathrm{I}^{2}=72 \%$ ) (Figure 3 ). The GRADE was low because of concerns with the RoB 2 and the substantial heterogeneity, which indicated that "we have little confidence in the effect estimate and the true effect might be markedly different from the estimated effect" (Table 2). 


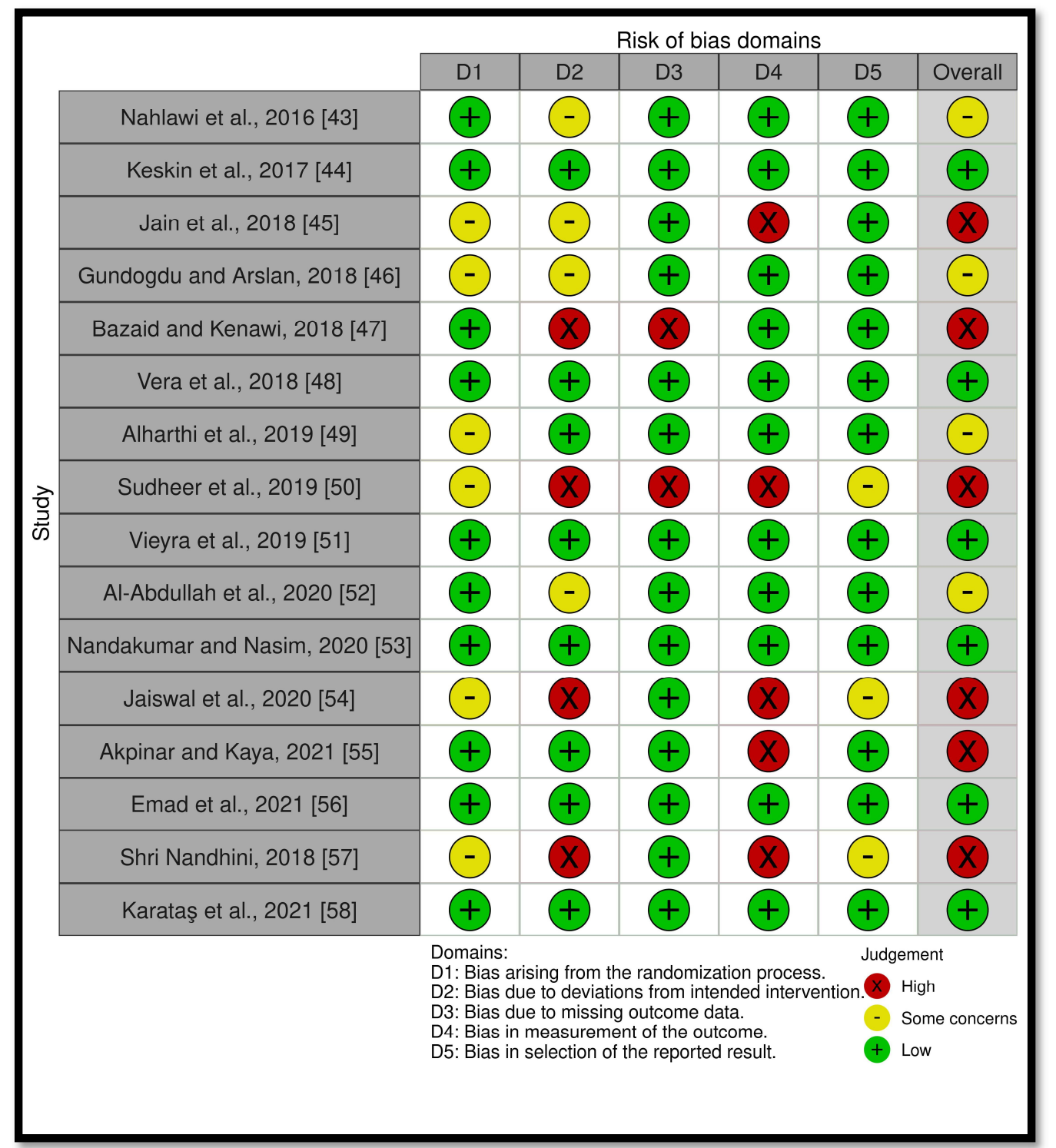

Figure 2. Summary of the risk assessment bias (RoB 2) of the included randomized controlled trials.

\begin{tabular}{|c|c|c|c|c|c|c|c|c|c|c|c|}
\hline \multirow{2}{*}{ Study or Subgroup } & \multicolumn{3}{|c|}{ Experimental group } & \multicolumn{3}{|c|}{ Control group } & Weight & $\begin{array}{l}\text { Mean Difference } \\
\text { IV, Random, } 95 \% \mathrm{CI}\end{array}$ & \multicolumn{2}{|c|}{$\begin{array}{l}\text { Mean Difference } \\
\text { IV, Random, } 95 \% \mathrm{Cl}\end{array}$} & \\
\hline & 1.85 & 1.8 & 30 & 3.433 & 2.05 & 30 & $14.8 \%$ & $-1.58[-2.56,-0.61]$ & 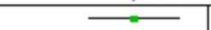 & & \\
\hline Vera et al., 2018 [48] & 1.59 & 1.9 & 93 & 3.53 & 1.9 & 93 & $19.9 \%$ & $-1.94[-2.49,-1.39]$ & $\rightarrow$ & & \\
\hline Shri Nandhini, 2018 [57] & 0.201 & 0.401 & 20 & 1.731 & 1.97 & 20 & $15.9 \%$ & $-1.53[-2.41,-0.65]$ & & & \\
\hline Alharthi et al., 2019 [49] & 0.786 & 1.369 & 35 & 1.143 & 1.657 & 35 & $17.9 \%$ & $-0.36[-1.07,0.36]$ & & 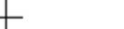 & \\
\hline Nandakumar and Nasim, 2020 [53] & 1.38 & 1.212 & 32 & 2.28 & 1.971 & 32 & $16.9 \%$ & $-0.90[-1.70,-0.10]$ & & & \\
\hline Jaiswal et al., $2020[54]$ & 1 & 1.362 & 15 & 1.2 & 1.424 & 15 & $14.6 \%$ & $-0.20[-1.20,0.80]$ & & & \\
\hline Total $(95 \% \mathrm{Cl})$ & & & 225 & & & 225 & $100.0 \%$ & $-1.11[-1.72,-0.50]$ & & & \\
\hline \multicolumn{9}{|c|}{$\begin{array}{l}\text { Heterogeneity. } \text { Tau }^{2}=0.41 ; \mathrm{Chi}^{2}=17.96, \mathrm{df}=5(\mathrm{P}=0.003) ; \mathrm{I}^{2}=72 \% \\
\text { Test for overall effect: } Z=3.54(P=0.0004)\end{array}$} & $\begin{array}{ll}1 & 1 \\
-4 & -1 \\
\text { Experimental group }\end{array}$ & Control gro & 4 \\
\hline
\end{tabular}

Figure 3. Forest plot comparing postoperative pain between the experimental group (intracanal cryotherapy) and the control group (room temperature) at $6 \mathrm{~h}$. IV: Intravitreal. 
Table 2. Certainty of evidence. Question: Is intracanal cryotherapy effective in reducing postoperative endodontic pain compared with a room temperature irrigant (Control)?; Setting: A dental clinic; Participants: Adult patients ( $\geq 18$ years old) with permanent teeth that have pulpal or periradicular pathosis; Intervention: Final irrigation with a cold irrigant; Comparator: Final irrigation with an irrigant at room temperature.

\begin{tabular}{|c|c|c|c|c|c|c|c|c|c|c|}
\hline \multicolumn{7}{|c|}{ Certainty Assessment } & \multicolumn{2}{|c|}{ Number of Patients } & \multirow{2}{*}{$\begin{array}{c}\text { Effect } \\
\begin{array}{c}\text { Mean } \\
\text { Difference } \\
(95 \% \text { CI *) }\end{array}\end{array}$} & \multirow[b]{2}{*}{ Certainty ${ }^{\S}$} \\
\hline $\begin{array}{l}\text { Number } \\
\text { of } \\
\text { Studies }\end{array}$ & $\begin{array}{l}\text { Study } \\
\text { Design }\end{array}$ & $\begin{array}{c}\text { Risk of } \\
\text { Bias }\end{array}$ & Inconsistency & Indirectness & Imprecision & $\begin{array}{l}\text { Other Con- } \\
\text { siderations }\end{array}$ & $\begin{array}{l}\text { Intracanal } \\
\text { Cryother- } \\
\text { apy }\end{array}$ & $\begin{array}{l}\text { Room Tem- } \\
\text { perature } \\
\text { Irrigant } \\
\text { (Control) }\end{array}$ & & \\
\hline \multicolumn{11}{|c|}{ Postoperative pain at $6 \mathrm{~h}$} \\
\hline 6 & $\begin{array}{l}\text { Randomized } \\
\text { clinical trials }\end{array}$ & Serious ${ }^{a}$ & Serious ${ }^{b}$ & $\begin{array}{l}\text { Not } \\
\text { serious }\end{array}$ & ${ }_{\text {serious }}^{\text {Not }}$ & None & 225 & 225 & $\begin{array}{c}-1.11 \\
(-1.72 \\
\text { to }-0.5)\end{array}$ & $\begin{array}{l}\oplus \oplus \bigcirc \bigcirc \\
\text { LOW }\end{array}$ \\
\hline \multicolumn{11}{|c|}{ Postoperative pain at $24 \mathrm{~h}$} \\
\hline 9 & $\begin{array}{l}\text { Randomized } \\
\text { clinical trials }\end{array}$ & Serious ${ }^{a}$ & Serious ${ }^{b}$ & ${ }_{\text {serious }}^{\text {Not }}$ & ${ }_{\text {serious }}^{\text {Not }}$ & None & 422 & 341 & $\begin{array}{c}-1.08 \\
(-1.79 \\
\text { to }-0.38)\end{array}$ & $\begin{array}{l}\oplus \oplus \bigcirc \bigcirc \\
\text { LOW }\end{array}$ \\
\hline \multicolumn{11}{|c|}{ Postoperative pain at $48 \mathrm{~h}$} \\
\hline 5 & $\begin{array}{l}\text { Randomized } \\
\text { clinical trials }\end{array}$ & Serious ${ }^{a}$ & Serious ${ }^{b}$ & $\begin{array}{c}\text { Not } \\
\text { serious }\end{array}$ & $\underset{\text { serious }}{\text { Not }}$ & None & 260 & 180 & $\begin{array}{c}-0.38 \\
(-0.73 \\
\text { to }-0.02)\end{array}$ & $\begin{array}{l}\oplus \oplus \bigcirc \bigcirc \\
\text { LOW }\end{array}$ \\
\hline \multicolumn{11}{|c|}{ Postoperative pain at $72 \mathrm{~h}$} \\
\hline 5 & $\begin{array}{l}\text { Randomized } \\
\text { clinical trials }\end{array}$ & Serious ${ }^{a}$ & Serious ${ }^{b}$ & $\begin{array}{l}\text { Not } \\
\text { serious }^{c}\end{array}$ & $\underset{\text { serious }}{\text { Not }}$ & None & 290 & 209 & $\begin{array}{c}-0.69 \\
(-1.34 \\
\text { to }-0.05)\end{array}$ & $\begin{array}{l}\oplus \oplus \bigcirc \bigcirc \\
\text { LOW }\end{array}$ \\
\hline
\end{tabular}

*CI: Confidence interval; ${ }^{\S}$ GRADE (Grading of Recommendations, Assessment, Development and Evaluation) certainty ratings: very low certainty: the authors have very little confidence in the effect estimate (the true effect is probably markedly different from the estimated effect); low certainty: the authors have little confidence in the effect estimate (the true effect might be markedly different from the estimated effect); moderate certainty: the authors have moderate confidence in the effect estimate (the authors believe that the true effect is probably close to the estimated effect); high certainty: the authors have a lot of confidence that the true effect is similar to the estimated effect; ${ }^{a}$ concerns of a risk of bias; ${ }^{b}$ substantial heterogeneity; ${ }^{c}$ direct comparison; ${ }^{d}$ narrow confidence interval.

\subsection{Postoperative Pain at $24 \mathrm{~h}$}

Nine studies $(n=763)$ revealed postoperative pain at $24 \mathrm{~h}[45,46,48,49,51,53,54,57,58]$. A meta-analysis demonstrated a significant statistical diminution in postoperative pain in the intracanal cold therapy group (experimental group) compared with the room temperature irrigant group (control group) $(\mathrm{MD}=-1.08 ; 95 \% \mathrm{CI}=-1.79$ to $-0.38 ; p=0.003$; $\mathrm{I}^{2}=92 \%$ ) (Figure 4 ). The GRADE was low because of concerns with the RoB 2 and the substantial heterogeneity, which indicated that "we have little confidence in the effect estimate and the true effect might be markedly different from the estimated effect" (Table 2).

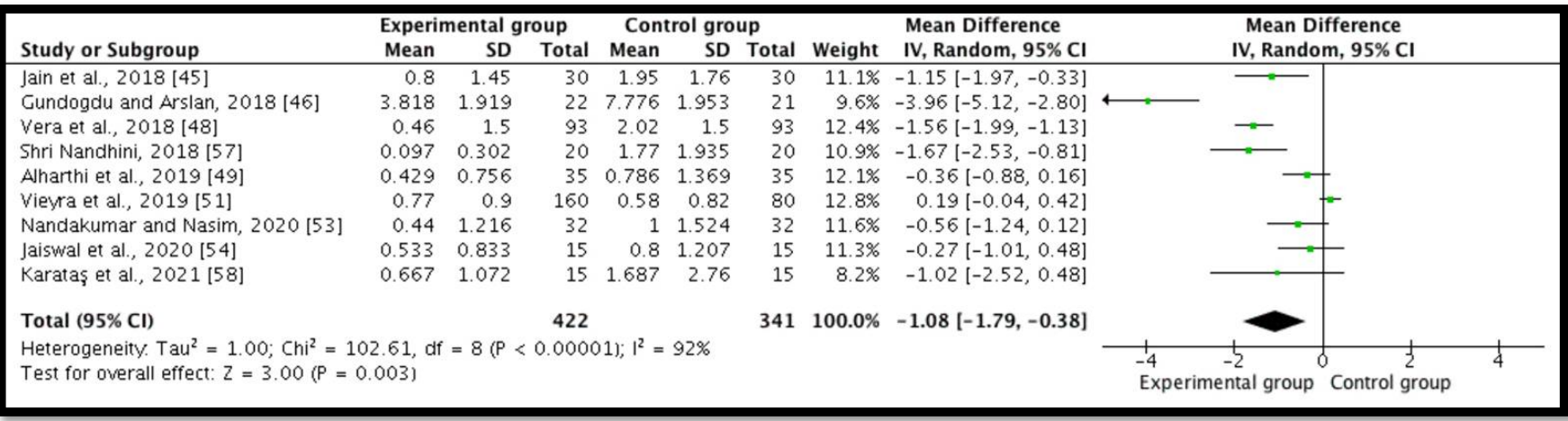

Figure 4. Forest plot comparing postoperative pain between the experimental group (intracanal cryotherapy) and the control group (room temperature) at $24 \mathrm{~h}$.

\subsection{Postoperative Pain at $48 \mathrm{~h}$}

Five studies $(n=440)$ revealed postoperative pain at $48 \mathrm{~h}[45,49,51,57,58]$. A metaanalysis demonstrated a significant statistical diminution in postoperative pain in the intracanal cold therapy group (experimental group) compared with the room temperature 
irrigant group (control group) $\left(\mathrm{MD}=-0.38 ; 95 \% \mathrm{CI}=-0.73\right.$ to $-0.02 ; p=0.04 ; \mathrm{I}^{2}=81 \%$ ) (Figure 5). The GRADE was low because of concerns with the RoB 2 and the substantial heterogeneity, which indicated that "we have little confidence in the effect estimate and the true effect might be markedly different from the estimated effect" (Table 2).

\begin{tabular}{|c|c|c|c|c|c|c|c|c|c|c|}
\hline \multirow[b]{2}{*}{ Study or Subgroup } & \multicolumn{3}{|c|}{ Experimental group } & \multicolumn{3}{|c|}{ Control group } & \multirow[b]{2}{*}{ Weight } & \multirow{2}{*}{$\begin{array}{l}\text { Mean Difference } \\
\text { IV, Random, } 95 \% \mathrm{CI}\end{array}$} & \multirow{2}{*}{$\begin{array}{c}\text { Mean Difference } \\
\text { IV, Random, } 95 \% \mathrm{CI}\end{array}$} & \\
\hline & Mean & SD & Total & Mean & SD & Total & & & & \\
\hline Jain et al., 2018 [45] & 0.35 & 0.93 & 30 & 1.15 & 1.57 & 30 & $15.8 \%$ & $-0.80[-1.45,-0.15]$ & $\longrightarrow$ & \\
\hline Shri Nandhini, 2018 [57] & 0.038 & 0.17 & 20 & 1.311 & 1.461 & 20 & $16.0 \%$ & $-1.27[-1.92,-0.63]$ & $\longrightarrow-$ & \\
\hline Alharthi et al., 2019 [49] & 0.071 & 0.267 & 35 & 0.143 & 0.535 & 35 & $30.6 \%$ & $-0.07[-0.27,0.13]$ & 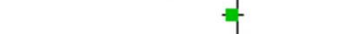 & \\
\hline Vieyra et al., 2019 [51] & 0.25 & 0.5 & 160 & 0.23 & 0.44 & 80 & $32.5 \%$ & $0.02[-0.10,0.14]$ & & \\
\hline Karataş et al., 2021 [58] & 0.813 & 1.017 & 15 & 1.413 & 2.711 & 15 & $5.0 \%$ & $-0.60[-2.07,0.87]$ & & \\
\hline Total $(95 \% \mathrm{Cl})$ & & & 260 & & & 180 & $100.0 \%$ & $-0.38[-0.73,-0.02]$ & & \\
\hline \multicolumn{7}{|c|}{$\begin{array}{l}\text { Heterogeneity. } \mathrm{Tau}^{2}=0.10 ; \mathrm{Chi}^{2}=20.68, \mathrm{df}=4(\mathrm{P}=0.0004) ; \mathrm{I}^{2}=81 \% \\
\text { Test for overall effect: } Z=2.07(\mathrm{P}=0.04)\end{array}$} & & & $\begin{array}{lll}-4 & -2 & 1 \\
\text { Experimental group Control gro } & 2\end{array}$ & 4 \\
\hline
\end{tabular}

Figure 5. Forest plot comparing postoperative pain between the experimental group (intracanal cryotherapy) and the control group (room temperature) at $48 \mathrm{~h}$.

\subsection{Postoperative Pain at $72 \mathrm{~h}$}

Five studies $(n=563)$ revealed postoperative pain at $72 \mathrm{~h}[46,48,51,53,58]$. However, one study had zero scores for the mean and standard deviation for the intracanal cold therapy group (experimental group) [53]; therefore, the MD and CI were not estimable and they were not included in the statistics. A meta-analysis demonstrated a significant statistical diminution in postoperative pain in the intracanal cold therapy group (experimental group) compared with the room temperature irrigant group (control group) $(\mathrm{MD}=-0.69$; $95 \% \mathrm{CI}=-1.34$ to $-0.05 ; p=0.04 ; \mathrm{I}^{2}=90 \%$ ) (Figure 6 ). The GRADE was low because of concerns with the RoB 2 and the substantial heterogeneity, which indicated that "we have little confidence in the effect estimate and the true effect might be markedly different from the estimated effect" (Table 2).

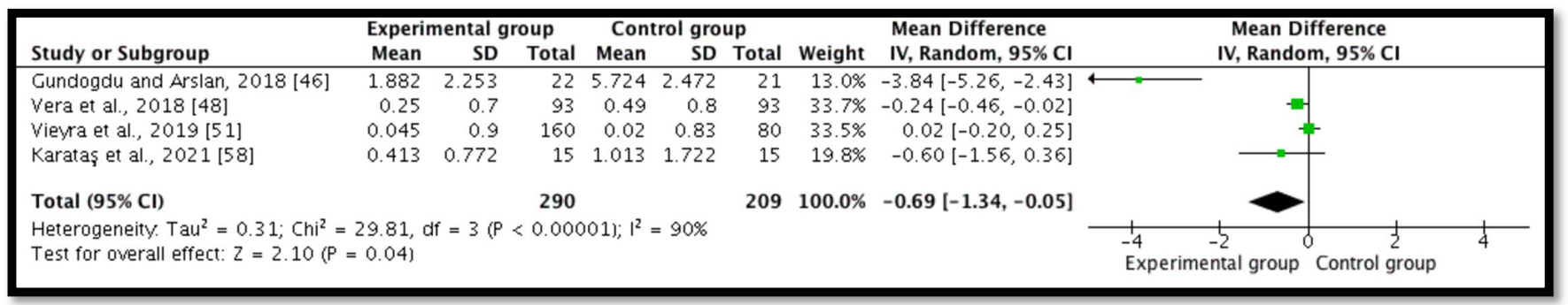

Figure 6. Forest plot comparing postoperative pain between the experimental group (intracanal cryotherapy) and the control group (room temperature) at $72 \mathrm{~h}$.

\subsection{Postoperative Pain at 7 Days}

Three studies $(n=113)$ revealed postoperative pain at seven days $[46,57,58]$. Two of these studies $[57,58]$ had zero scores for the mean and standard deviation for the experimental group. Therefore, the MD and CI were not estimable.

\section{Discussion}

The present systematic review and meta-analysis showed that the application of intracanal cryotherapy minimized endodontic pain at $6,24,48$, and $72 \mathrm{~h}$ postoperatively. These results were consistent with previous systematic reviews [59,60]. However, Monteiro et al. in their systematic review and meta-analysis showed that pain was only minimized 6 and $24 \mathrm{~h}$ postoperatively [61]. After seven days, there was a reduction in the postoperative pain scores in the intracanal cryotherapy group (experimental group) compared with the room temperature group (control group) but this reduction could not be proven 
statistically due to inestimable MD and CI values. Our results were in contrast with those reported by Gupta et al. in their systematic review and meta-analysis where they showed that intracanal cryotherapy did not play a significant role in minimizing postendodontic pain [62]. Pain reduction after cryotherapy application is due to several mechanisms including changes in the nerve conduction velocity, inhibition of nociceptors, and a reduction in the metabolic enzyme activity level [67-69]. It has been reported that at a $7{ }^{\circ} \mathrm{C}$ body temperature, myelinated A- $\delta$ fibers are completely deactivated; nonmyelinated C-fibers are deactivated at $3{ }^{\circ} \mathrm{C}[70,71]$. Moreover, Vera et al. in their in vitro study concluded that finalizing the irrigation with a $2.5^{\circ} \mathrm{C}$ saline solution decreased the temperature of the external root surface by more than $10{ }^{\circ} \mathrm{C}$ for a $4 \mathrm{~min}$ period. This decrease in temperature is sufficient to decelerate the inflammatory reaction and reduce the induction of pain-producing substances, leading to local anti-inflammatory effects in the periradicular tissues [36]. Eight of the thirteen studies that compared the use of analgesics between the intracanal cold therapy and the control groups postoperatively showed that fewer patients used analgesics in the intracanal cold therapy group than in the control group. A previous systematic review analyzed the effect of cold therapy on pain reduction and analgesic use after a total knee arthroplasty. Very low certainty evidence was found that cold therapy decreased analgesic use and no evidence showed that it reduced pain [72]. On the other hand, Watkins et al. concluded that cryotherapy decreases postoperative pain and the use of analgesics by patients undergoing major abdominal operations [24].

Our included studies had different numbers of treatment visits to perform root canal treatment; nine studies mentioned that root canal treatment was completed in one visit $[43,44,46,49-53,57]$, six studies performed root canal treatment in two visits $[45,47,48,54-56]$, and one study did not mention any information about the number of root canal treatment visits [58]. However, all of them showed a reduction in postoperative pain compared with preoperative pain. This is consistent with a previous systematic review that evaluated the predictors of postoperative endodontic pain and concluded that the number of treatment visits had no significant effect on postoperative pain [73]. On the other hand, Izadpanah et al. in their systematic review and meta-analysis concluded that single-visit root canal therapy has a higher risk of postoperative pain than multiple visits with acceptable statistical heterogeneity and a moderate quality of the studies [74].

The temperature of the final cold irrigant ranged from $1.5^{\circ} \mathrm{C}$ to $4{ }^{\circ} \mathrm{C}$ for 1 to $5 \mathrm{~min}$ among the included studies. The optimal temperature application duration of intracanal cold therapy has not been concluded as none of the studies compared the durations; however, a continuous exposure to a low temperature below $-20{ }^{\circ} \mathrm{C}$ leads to cell death and tissue destruction $[75,76]$ and intermittent applications of cryotherapy can enhance its therapeutic effect in relieving pain after an acute soft tissue injury [77].

An EndoVac negative pressure irrigation system was used along with needle syringe activation in five studies $[43,44,48,51,57]$. A previous systematic review analyzed the effect of using an EndoVac versus a needle syringe in controlling postoperative pain; no statistically significant difference was found [60]. On the other hand, it was shown that an EndoVac might cause less postoperative pain due to less apical extrusion of debris [78].

To the best of our knowledge, this is the first systematic review that determined the effect of intracanal cold therapy on postoperative endodontic pain by utilizing the second version of the Cochrane risk of bias tool for randomized trials (RoB 2). The Cochrane risk of bias tool 2 ( $R o B$ 2) is designed to focus on the results, leading to a better quality of the risk of bias assessments. Furthermore, the RoB 2 has an approach that applies a granular structure of knowledge by indicating questions and a wider range of possible answers that guide the review authors to focus on the context of clinical trials [79].

In our systematic review, a few concerns of bias arose from the randomization process due to a lack of information about the randomization and the concealment of the allocation process $[45,46,49,50,54,57]$. A bias associated with inadequate allocation concealment may cause an exaggeration of the estimated treatment effect and affect the meta-analysis results [80]. A bias due to deviations from the intended intervention was observed in eight 
studies where the people delivering the interventions were not blinded and no information was provided regarding the blinding of the participants $[43,45-47,50,51,54,57]$. A previous study found that the risk of bias in blinding the participants and personnel in endodontics clinical trials is the highest and will lead to an overestimation of the results [81]. Missing outcome data were not clear in two studies [47,50], which might lead to doubts regarding the estimate of the effect [82]. The outcome of postoperative pain was assessed by the patients themselves and no information was provided regarding the awareness of the outcome assessors of the intervention they received in five studies $[45,50,54,55,57]$. That might lead to bias in the outcome measurement. A bias in the selection of the reported result was found in three studies $[50,54,57]$, which might cause misleading results. These biases might explain the significant reduction in postoperative endodontic pain at 6, 24, 48, and $72 \mathrm{~h}$ that was found in the meta-analysis.

The GRADE was utilized to rate the certainty of evidence and it was found to be low due to serious concerns about the risk of bias and inconsistency. These results were in contrast to a previous systematic review that also evaluated the efficacy of intracanal cold therapy for the management of postoperative endodontic pain and the certainty of evidence was judged as moderate [60]. Another systematic review evaluated the same topic but the certainty of evidence was considered very low due to serious concerns with the risk of bias and inconsistency as well as very serious concerns with the imprecision [61].

This systematic review has a few limitations including the variability among the included studies in the study design, the diagnosis of pulpal and periapical areas, the type of teeth included in each study, the preoperative pain status, the experimental group irrigation protocol, the sample size, and the number of treatment visits. These variations among the included studies might affect the intervention effects.

Although intracanal cryotherapy is a simple and inexpensive method that might reduce postoperative endodontic pain, the certainty of evidence illustrated in this research was low. This signifies the need for well-designed trials with precise parameters and variable controls to establish its effective and definitive use in endodontic clinical practice.

\section{Conclusions}

Within the limitations of this study, the application of intracanal cold irrigation showed low certainty of evidence in reducing postoperative endodontic pain. Additional better designed clinical trials are required to establish the effective use of intracanal cryotherapy in controlling postoperative endodontic pain in clinical practice.

Author Contributions: Conceptualization; A.A. and E.A.-M.; methodology, A.A. and E.A.-M.; software, A.A.; validation, A.A. and E.A.-M.; formal analysis, A.A. and E.A.-M.; investigation, A.A. and E.A.-M.; resources, A.A. and E.A.-M.; data curation, A.A. and E.A.-M.; writing-original draft preparation, A.A.; writing-review and editing, E.A.-M. All authors have read and agreed to the published version of the manuscript.

Funding: This research received no external funding.

Institutional Review Board Statement: Not applicable.

Informed Consent Statement: Not applicable.

Conflicts of Interest: The authors declare no conflict of interest.

\section{References}

1. Gotler, M.; Bar-Gil, B.; Ashkenazi, M. Postoperative Pain after Root Canal Treatment: A Prospective Cohort Study. Int. J. Dent. 2012, 2012, 1-5. [CrossRef]

2. Sathorn, C.; Parashos, P.; Messer, H. The prevalence of postoperative pain and flare-up in single- and multiple-visit endodontic treatment: A systematic review. Int. Endod. J. 2007, 41, 91-99. [CrossRef]

3. Nixdorf, D.R.; Moana-Filho, E.; Law, A.S.; McGuire, L.; Hodges, J.S.; John, M.T. Frequency of Persistent Tooth Pain after Root Canal Therapy: A Systematic Review and Meta-Analysis. J. Endod. 2010, 36, 224-230. [CrossRef] [PubMed] 
4. Vena, D.A.; Collie, D.; Wu, H.; Gibbs, J.L.; Broder, H.L.; Curro, F.A.; Thompson, V.P.; Craig, R.G. Prevalence of Persistent Pain 3 to 5 Years Post Primary Root Canal Therapy and Its Impact on Oral Health-Related Quality of Life: PEARL Network Findings. J. Endod. 2014, 40, 1917-1921. [CrossRef] [PubMed]

5. Polycarpou, N.; Ng, Y.-L.; Canavan, D.; Moles, D.R.; Gulabivala, K. Prevalence of persistent pain after endodontic treatment and factors affecting its occurrence in cases with complete radiographic healing. Int. Endod. J. 2005, 38, 169-178. [CrossRef] [PubMed]

6. Nixdorf, D.R.; Law, A.S.; Lindquist, K.; Reams, G.J.; Cole, E.; Kanter, K.; Nguyen, R.H.N.; Harris, D.R. Frequency, impact, and predictors of persistent pain after root canal treatment: A national dental PBRN study. Pain 2016, 157, 159-165. [CrossRef]

7. Sjögren, J.J.; Kvist, T.; Eliasson, A.; Co, E.R.; Pigg, M. The frequency and characteristics of pain and discomfort associated with root filled teeth: A practice-based study. Int. Endod. J. 2019, 52, 1264-1273. [CrossRef] [PubMed]

8. Vishwanathaiah, S.; Maganur, P.; Khanagar, S.; Chohan, H.; Testarelli, L.; Mazzoni, A.; Gupta, A.; Raj, A.; Bhandi, S.; Mehta, D.; et al. The Incidence and Intensity of Postendodontic Pain and Flareup in Single and Multiple Visit Root Canal Treatments: A Systematic Review and Meta-Analysis. Appl. Sci. 2021, 11, 3358. [CrossRef]

9. Mostafa, M.E.H.A.A.; El-Shrief, Y.A.I.; Anous, W.I.O.; Hassan, M.W.; Salamah, F.T.A.; El Boghdadi, R.M.; El-Bayoumi, M.A.A.; Seyam, R.M.; Abd-El-Kader, K.G.; Amin, S.A.W. Postoperative pain following endodontic irrigation using $1.3 \%$ versus 5.25\% sodium hypochlorite in mandibular molars with necrotic pulps: A randomized double-blind clinical trial. Int. Endod. J. 2020, 53, 154-166. [CrossRef]

10. Mehrvarzfar, P.; Abbott, P.V.; Saghiri, M.A.; Delvarani, A.; Asgar, K.; Lotfi, M.; Karamifar, K.; Kharazifard, M.J.; Khabazi, H. Effects of three oral analgesics on postoperative pain following root canal preparation: A controlled clinical trial. Int. Endod. J. 2011, 45, 76-82. [CrossRef]

11. Pochapski, M.T.; Santos, A. Effect of pretreatment dexamethasone on postendodontic pain. Oral Surg. Oral Med. Oral Pathol. Oral Radiol. Endod. 2009, 108, 790-795. [CrossRef]

12. Arslan, H.; Gundogdu, E.C.; Sumbullu, M. The Effect of Preoperative Administration of Antihistamine, Analgesic and Placebo on Postoperative Pain in Teeth with Symptomatic Apical Periodontitis: A Randomized Controlled Trial. Eur. Endod. J. 2017, 1, 1. [CrossRef]

13. Yıldız, E.D.; Arslan, H. Effect of Low-level Laser Therapy on Postoperative Pain in Molars with Symptomatic Apical Periodontitis: A Randomized Placebo-controlled Clinical Trial. J. Endod. 2018, 44, 1610-1615. [CrossRef] [PubMed]

14. Tupyota, P.; Dds, P.C.; Laopaiboon, M.; Ngamjarus, C.; Abbott, P.V.; Krisanaprakornkit, S. Supplementary techniques for pain control during root canal treatment of lower posterior teeth with irreversible pulpitis: A systematic review and meta-analysis. Aust. Endod. J. 2018, 44, 14-25. [CrossRef] [PubMed]

15. Menakaya, I.N.; Oderinu, O.H.; Adegbulugbe, I.C.; Shaba, O.P. Incidence of postoperative pain after use of calcium hydroxide mixed with normal saline or $0.2 \%$ chlorhexidine digluconate as intracanal medicament in the treatment of apical periodontitis. Saudi Dent. J. 2015, 27, 187-193. [CrossRef] [PubMed]

16. Parirokh, M.; Rekabi, A.R.; Ashouri, R.; Nakhaee, N.; Abbott, P.; Gorjestani, H. Effect of Occlusal Reduction on Postoperative Pain in Teeth with Irreversible Pulpitis and Mild Tenderness to Percussion. J. Endod. 2013, 39, 1-5. [CrossRef]

17. Harirforoosh, S.; Asghar, W.; Jamali, F. Adverse effects of nonsteroidal anti-inflammatory drugs: An update of gastrointestinal, cardiovascular and renal complications. J. Pharm. Pharm. Sci. 2013, 16, 821-847. [CrossRef]

18. Hargreaves, K.; Abbott, P.V. Drugs for pain management in dentistry. Aust. Dent. J. 2005, 50, S14-S22. [CrossRef]

19. Guerreiro, M.Y.R.; Monteiro, L.P.B.; de Castro, R.F.; Magno, M.B.; Maia, L.C.; Brandão, J.M.D.S. Effect of low-level laser therapy on postoperative endodontic pain: An updated systematic review. Complement. Ther. Med. 2021, 57, 102638. [CrossRef]

20. Emara, R.S.; El Nasr, H.M.A.; El Boghdadi, R.M. Evaluation of postoperative pain intensity following occlusal reduction in teeth associated with symptomatic irreversible pulpitis and symptomatic apical periodontitis: A randomized clinical study. Int. Endod. J. 2018, 52, 288-296. [CrossRef]

21. Fayyad, D.M.; Abdelsalam, N.; Hashem, N. Cryotherapy: A New Paradigm of Treatment in Endodontics. J. Endod. 2020, 46, 936-942. [CrossRef]

22. Nayeema, S.; Subha, D.R. Cryotherapy-A novel treatment modality in oral lesions. Int. J. Pharm. Pharm. Sci. 2013, 5, 4-5.

23. Higgins, T.R.; Heazlewood, I.T.; Climstein, M. A Random Control Trial of Contrast Baths and Ice Baths for Recovery during Competition in U/20 Rugby Union. J. Strength Cond. Res. 2011, 25, 1046-1051. [CrossRef]

24. Watkins, A.A.; Johnson, T.V.; Shrewsberry, A.B.; Nourparvar, P.; Madni, T.; Watkins, C.J.; Feingold, P.; Kooby, D.A.; Maithel, S.K.; Staley, C.A.; et al. Ice Packs Reduce Postoperative Midline Incision Pain and Narcotic Use: A Randomized Controlled Trial. J. Am. Coll. Surg. 2014, 219, 511-517. [CrossRef] [PubMed]

25. Laureano Filho, J.R.; e Silva, E.D.d.O.; Batista, C.I.; Gouveia, F.M.V. The influence of cryotherapy on reduction of swelling, pain and trismus after third-molar extraction: A preliminary study. J. Am. Dent. Assoc. 2005, 136, 774-778. [CrossRef]

26. Cryotherapy on Inflammatory Profile and Postoperative Pain Levels in Endodontic Infections. Available online: https:// clinicaltrials.gov/ct2/show / NCT04798144 (accessed on 8 August 2021).

27. Comparing the Effect of Cold Application and Low Level Laser Application on Pain and Quality of Life in Patients Following Root Canal Treatment. CTRI/2021/02/030939. 2021. Available online: http://www.who.int/trialsearch/Trial2.aspx?TrialID= CTRI/2021/02/030939 (accessed on 8 August 2021). 
28. Evaluation of Post-Operative Pain and Expression of IL-8 Using Ketolac or Cryoirrigation as a Final Flush in Single Visit Endodontic Treatment in Teeth With Symptomatic Irreversible Pulpitis and Apical Periodontitis. Randomized Clinical Trial. Available online: https:/ / clinicaltrials.gov/ct2/show/NCT04733326 (accessed on 8 August 2021).

29. Comparison between Low-level Laser Therapy, Intracanal Cryotherapy and Their Combination, on Post-endodontic Pain Level. Available online: https:/ / clinicaltrials.gov/ct2/show / NCT04006717 (accessed on 8 August 2021).

30. Role of Cryotherapy in Reduction of Post Operative Endodontic Pain Following Single Visit Root Canal Therapy. Available online: https: / / clinicaltrials.gov/ct2/show / NCT03044470 (accessed on 8 August 2021).

31. Influence of Intra-Canal Cryotherapy on Post-Endodontic Pain and Interleukin-6 Expression Using Different Irrigation Protocols: A Randomized Clinical Trial. Available online: https:/ / clinicaltrials.gov/ct2/show / NCT04324398 (accessed on 8 August 2021).

32. Effect of Cold Saline Irrigation during Root Canal Treatment on Postoperative Pain in Symptomatic Teeth. Available online: https:/ / www.cochranelibrary.com/central/doi/10.1002/central/CN-02065891/full (accessed on 8 August 2021).

33. A Clinical Study to See the Post Treatment Pain in Painful Irreversible Pulpal Diseases after Single Visit Root Canal Treatment Using Cold Saline as Irrigation Method. Available online: https://www.cochranelibrary.com/central/doi/10.1002/central/CN01906679/full (accessed on 8 August 2021).

34. A Clinical Research to Know the Effect of Cold Pack Application on Pain during Root Canal Treatment. Available online: https:/ / www.cochranelibrary.com/central/doi/10.1002/central/CN-01975236/full (accessed on 8 August 2021).

35. Effect of Cryotherapy on Postoperative Pain. Available online: https://www.cochranelibrary.com/central/doi/10.1002/central/ CN-01648158/full (accessed on 8 August 2021).

36. Vera, J.; Ochoa-Rivera, J.; Vazquez-Carcaño, M.; Romero, M.; Arias, A.; Sleiman, P. Effect of Intracanal Cryotherapy on Reducing Root Surface Temperature. J. Endod. 2015, 41, 1884-1887. [CrossRef] [PubMed]

37. Keskin, C.; Sariyilmaz, E.; Keleş, A.; Güler, D.H. Effect of intracanal cryotherapy on the fracture resistance of endodontically treated teeth. Acta Odontol. Scand. 2019, 77, 164-167. [CrossRef]

38. Brignardello-Petersen, R. Cold irrigation results in less severe pain after root canal treatment than conventional irrigation in teeth with symptomatic apical periodontitis, but the difference may be negligible after the first day. J. Am. Dent. Assoc. 2017, 149, e48. [CrossRef]

39. Sadaf, D.-E. Limited Quality Evidence Suggests that Application of Cryotherapy May Be Helpful in Reducing Postoperative Pain in Root Canal Therapy in Patients with Symptomatic Apical Periodontitis. J. Evid. Based Dent. Pr. 2019, 19, 195-197. [CrossRef]

40. Gurucharan, I.; Saravana Karthikeyan, B.; Mahalaxmi, S. Intracanal cryotherapy in endodontics. Aust. Endod. J. 2017, 43, 138-139. [CrossRef]

41. Keskin, C.; Ozdemir, O. Response to the letter to the editor from Ishawarya Gurucharan. Aust. Endod. J. 2017, 43, 140. [CrossRef] [PubMed]

42. Reduction of Post-Endodontic Pain after RCT when Intracanal Cryotherapy Is Used. (PEP). Available online: https://www. cochranelibrary.com/central/doi/10.1002/central/CN-01483509/full (accessed on 8 August 2021).

43. Al-Nahlawi, T.; Abo Hatab, T.; Abd Alrazak, M.; Al-Abdullah, A. Effect of Intracanal Cryotherapy and Negative Irrigation Technique on Postendodontic Pain. J. Contemp. Dent. Pract. 2016, 17, 990-996. [CrossRef] [PubMed]

44. Keskin, C.; Özdemir, Ö.; Uzun, I.; Güler, B. Effect of intracanal cryotherapy on pain after single-visit root canal treatment. Aust. Endod. J. 2017, 43, 83-88. [CrossRef] [PubMed]

45. Jain, A.; Davis, D.; Bahuguna, R.; Agrawal, A.; Singh, S.; Ramachandran, R.; Varghese, A. Role of Cryotherapy in Reducing Postoperative Pain In Patients With Irreversible Pulpitis; An In-Vivo Study. Int. J. Dent. Med. Sci. Res. 2018, 2, 43-49.

46. Gundogdu, E.C.; Arslan, H. Effects of Various Cryotherapy Applications on Postoperative Pain in Molar Teeth with Symptomatic Apical Periodontitis: A Preliminary Randomized Prospective Clinical Trial. J. Endod. 2018, 44, 349-354. [CrossRef]

47. Bazaid, D.S.; Kenawi, L.M.M. The Effect of Intracanal Cryotherapy in Reducing Postoperative Pain in Patients with Irreversible Pulpitis: A Randomized Control Trial. Int. J. Health Sci. 2018, 8, 83-88.

48. Vera, J.; Ochoa, J.; Romero, M.; Vazquez-Carcaño, M.; Ramos-Gregorio, C.O.; Aguilar, R.R.; Cruz, A.; Sleiman, P.; Arias, A. Intracanal Cryotherapy Reduces Postoperative Pain in Teeth with Symptomatic Apical Periodontitis: A Randomized Multicenter Clinical Trial. J. Endod. 2018, 44, 4-8. [CrossRef]

49. Alharthi, A.A.; Aljoudi, M.H.; Almaliki, M.N.; Almalki, M.A.; Sunbul, M.A. Effect of intra-canal cryotherapy on post-endodontic pain in single-visit RCT: A randomized controlled trial. Saudi Dent. J. 2019, 31, 330-335. [CrossRef]

50. Sudheer, K.A.; Idris, M.; Geeta, I.B.; George, J.A. Effect of post endodontic pain after single sitting root canal treatment in vital tooth following final irrigation with cold saline. IJSR 2019, 8, 41-43.

51. Vieyra, J.P.; Enriquez, F.J.J.; Acosta, F.O.; Guardado, J.A. Reduction of post endodontic pain after one-visit root canal treatment using three irrigating regimens with different temperature. Niger. J. Clin. Pr. 2019, 22, 34-40.

52. Al-Abdullah, A.; Abdullah, A.; Al-Marrawi, K. Comparative study to investigate the effect of cryotherapy on post-operative pain using two different preparation techniques (in vivo study). Int. J. Appl. Dent. Sci. 2020, 6, 163-168.

53. Nasim, I.; Nandakumar, M. Effect of intracanal cryotreated sodium hypochlorite on postoperative pain after root canal treatmentA randomized controlled clinical trial. J. Conserv. Dent. 2020, 23, 131-136. [CrossRef]

54. Jaiswal, S.; Vagarali, H.; Pujar, M.; Kapshe, N. Effect of cold saline irrigation on postoperative pain-A randomized control trial. IP Indian J. Conserv. Endod. 2020, 5, 58-62. [CrossRef] 
55. Akpinar, K.E.; Kaya, F. Effect of different clinical practices on postoperative pain in permanent mandibular molar teeth with symptomatic apical periodontitis: A randomized controlled clinical trial. Niger. J. Clin. Pr. 2021, 24, 8-16.

56. Emad, A.; Abdelsalam, N.; Fayyad, D.M. Influence of intracanal cryptherapy on postendodontic pain and interleukin-6 expression using different irrigation protocols: A randomized clinical trial. Saudi. Endod. J. 2021, 11, $246-251$.

57. Nandhini, D.S. Effect of Cold Saline Solution as Final Irrigation on Postoperative Pain after Single Visit Root CANAL TreatmentAn In Vivo Study. Master's Thesis, The Tamil Nadu Dr. M.G.R. Medical Univesity, Chennai, India, 2018.

58. Karataş, E.; Ayaz, N.; Uluköylü, E.; Baltaci, M.Ö.; Adigüzel, A. Effect of final irrigation with sodium hypochlorite at different temperatures on postoperative pain level and antibacterial activity: A randomized controlled clinical study. J. Appl. Oral Sci. 2021, 29, e20200502. [CrossRef] [PubMed]

59. Pak, J.G.; White, S.N. Pain Prevalence and Severity before, during, and after Root Canal Treatment: A Systematic Review. J. Endod. 2011, 37, 429-438. [CrossRef]

60. Sadaf, D.; Ahmad, M.Z.; Onakpoya, I.J. Effectiveness of Intracanal Cryotherapy in Root Canal Therapy: A Systematic Review and Meta-analysis of Randomized Clinical Trials. J. Endod. 2020, 46, 1811-1823.e1. [CrossRef]

61. Monteiro, L.P.B.; Guerreiro, M.Y.R.; Valino, R.D.C.; Magno, M.B.; Maia, L.C.; Brandão, J.M.D.S. Effect of intracanal cryotherapy application on postoperative endodontic pain: A systematic review and metaanalysis. Clin. Oral Investig. 2021, 25, 23-35. [CrossRef]

62. Gupta, A.; Aggarwal, V.; Gurawa, A.; Mehta, N.; Abraham, D.; Singh, A.; Jala, S.; Chauhan, N. Effect of intracanal cryotherapy on postendodontic pain: A systematic review and meta-analysis of randomized controlled trials. J. Dent. Anesth. Pain Med. 2021, 21, 15-27. [CrossRef]

63. Moher, D.; Liberati, A.; Tetzlaff, J.; Altman, D.G. Preferred reporting items for systematic reviews and meta-analyses: The PRISMA statement. BMJ 2009, 339, 332-336. [CrossRef] [PubMed]

64. Higgins, J.; Altman, D. Assessing Risk of Bias in Included Studies. In Cochrane Handbook for Systematic Reviews of Interventions; John Wiley \& Sons, Ltd.: Hoboken, NJ, USA, 2008.

65. Sterne, J.A.C.; Savović, J.; Page, M.J.; Elbers, R.G.; Blencowe, N.S.; Boutron, I.; Cates, C.J.; Cheng, H.Y.; Corbett, M.S.; Eldridge, S.M.; et al. RoB 2: A revised tool for assessing risk of bias in randomized trials. BMJ 2019, 366, 14898. [CrossRef] [PubMed]

66. GRADE Working Group. Grading quality of evidence and strength of recommendations. BMJ 2004, 328, 1490. [CrossRef] [PubMed]

67. Wahren, L.K.; Torebjork, E.; Jorum, E. Central suppression of cold-induced C fiber pain by myelinated fiber input. Pain 1989, 38, 313-319. [CrossRef]

68. Konrath, G.A.; Lock, T.; Goitz, H.T.; Scheidler, J. The use of cold therapy after anterior cruciate ligament reconstruction: A prospective randomized study and literature review. Am. J. Sports. Med. 1996, 24, 629-633. [CrossRef]

69. Airaksinen, O.V.; Kyrklund, N.; Kouri, J.P.; Grönblad, M.; Kolari, P.; Latvala, K. Efficacy of Cold Gel for Soft Tissue Injuries. Am. J. Sports Med. 2003, 31, 680-684. [CrossRef]

70. Belitsky, R.B.; Odam, S.J.; Hubley-Kozey, C. Evaluation of the Effectiveness of Wet Ice, Dry Ice, and Cryogen Packs in Reducing Skin Temperature. Phys. Ther. 1987, 67, 1080-1084. [CrossRef]

71. Gade, V.; Barfiwala, D.; Asani, R.; Gawande, R.; Gade, J. Cryotherapy: An emerging trend in the field of endodontics. Int. J. Drug. Res. Dent. Sci. 2020, 2, 70-76.

72. Tedesco, D.; Gori, D.; Desai, K.R.; Asch, S.; Carroll, I.R.; Curtin, C.; McDonald, K.M.; Fantini, M.P.; Hernandez-Boussard, T. Drugfree interventions to reduce pain or opioid consumption after total knee arthroplasty: A systematic review and meta-analysis. JAMA Surg. 2017, 152, e172872. [CrossRef]

73. AlRahabi, M.K. Predictors, prevention, and management of postoperative pain associated with nonsurgical root canal treatment: A systematic review. J. Taibah Univ. Med. Sci. 2017, 12, 376-384. [CrossRef]

74. Izadpanah, A.; Javaheripour, A.; Maleki, A.; Alipour, M.; Hosseinifard, H.; Sharifi, S.; Dizaj, S.M. The Comparison of Short-Term Postoperative Pain in Single- versus Multiple-Visit Root Canal Treatment: A Systematic Review and Meta-Analysis Study. Pain Res. Manag. 2021, 2021, 1-12. [CrossRef]

75. Farah, C.S.; Savage, N.W. Cryotherapy for treatment of oral lesions. Aust. Dent. J. 2006, 51, 2-5. [CrossRef] [PubMed]

76. Zook, N.; Hussmann, J.; Brown, R.; Russell, R.; Kucan, J.; Roth, A.; Suchy, H.; Hussman, J.; Ross, A. Microcirculatory Studies of Frostbite Injury. Ann. Plast. Surg. 1998, 40, 246-255. [CrossRef]

77. Bleakley, C.M.; McDonough, S.M.; MacAuley, D.C. Cryotherapy for acute ankle sprains: A randomized controlled study of two different protocols. Br. J. Sports. Med. 2006, 40, 700-705. [CrossRef] [PubMed]

78. Gondim, E., Jr.; Setzer, F.C.; Dos Carmo, C.B.; Kim, S. Postoperative pain after the application of two different irrigation devices in a prospective randomized clinical trial. J. Endod. 2010, 36, 1295-1301. [CrossRef]

79. Higgins, J.P.; Savović, J.; Page, M.J.; Elbers, R.G.; Sterne, J.A. Assessing risk of bias in a randomized trial. Cochrane Handb. Syst. Rev. Interv. 2019, 205-228. [CrossRef]

80. Almeida, M.O.; Saragiotto, B.T.; Maher, C.G.; Oliveira, L.; Costa, P. Influence of allocation concealment and intention-to-treat analysis on treatment effects of physical therapy interventions in low back pain randomized controlled trials: A protocol of a meta-epidemiological study. BMJ 2017, 7, e017301. [CrossRef] 
81. Yi, J.; Li, H.; Li, Y.; Li, X.; Zheng, W.; Zhao, Z. Risk of Bias and Its Impact on Intervention Effect Estimates of Randomized Controlled Trials in Endodontics. J. Endod. 2020, 46, 12-18. [CrossRef]

82. Kirkham, J.; Dwan, K.M.; Altman, D.G.; Gamble, C.; Dodd, S.; Smyth, R.; Williamson, P.R. The impact of outcome reporting bias in randomised controlled trials on a cohort of systematic reviews. BMJ 2010, 340, c365. [CrossRef] 